Int. J. Electrochem. Sci., 14 (2019) $7016-7025$

International Journal of

ELECTROCHEMICAL

SCIENCE

www.electrochemsci.org

\title{
Faradaic Efficiencies for Methanol Oxidation in Proton- Exchange Membrane Electrolysis and Fuel Cells with Various Anode Catalysts
}

\author{
Rakan M. Altarawneh \\ Department of Chemistry, Faculty of Science, Mu'tah University, Al-Karak, Jordan \\ Corresponding author. Tel.: 00962776193935 \\ E-mail: $\underline{\text { rma766@mutah.edu.jo }}$
}

doi: $10.20964 / 2019.08 .79$

Received: 29 March 2019 / Accepted: 6 June 2019 / Published: 30 June 2019

The energy efficiency of a direct methanol fuel cell (DMFC) is dependent on the cell voltage, crossover of oxygen and/or methanol through the polymer electrolyte membrane, and stoichiometry of the methanol oxidation reaction (i.e., the average number of electrons transferred per methanol molecule $\left.\left(n_{a v}\right)\right)$. The stoichiometry is determined by the product distribution (carbon dioxide: formic acid: formaldehyde) and the amount of methanol consumed. The influence of crossover is investigated by using air and $\mathrm{N}_{2}$ at the cathode. Accurate determination of $n_{a v}$ requires analysis of the methanol and products from both the anode and cathode and quantitative determination of the consumption of methanol. In this work, $n_{a v}$ values obtained from the analysis of the cell exhausts by proton NMR and infrared spectrometry are compared with values obtained from a simple electrochemical method based on the dependence of the current on the flow rate of the methanol solution. The methodology presented here provides a comprehensive evaluation of methanol oxidation, along with a full determination of the methanol consumption and hence the fuel efficiency of the cell. The methods are suitable for rapid evaluation of catalysts in fuel cell hardware with low-cost online sensors for determination of product distributions.

Keywords: direct methanol fuel cell; methanol electrolysis cell; crossover; product distribution; flow rate; stoichiometry; efficiency

\section{FULL TEXT}

(C) 2019 The Authors. Published by ESG (www.electrochemsci.org). This article is an open access article distributed under the terms and conditions of the Creative Commons Attribution license (http://creativecommons.org/licenses/by/4.0/). 